\title{
The nutrition situation of free-living elderly in Umlazi township, South Africa
}

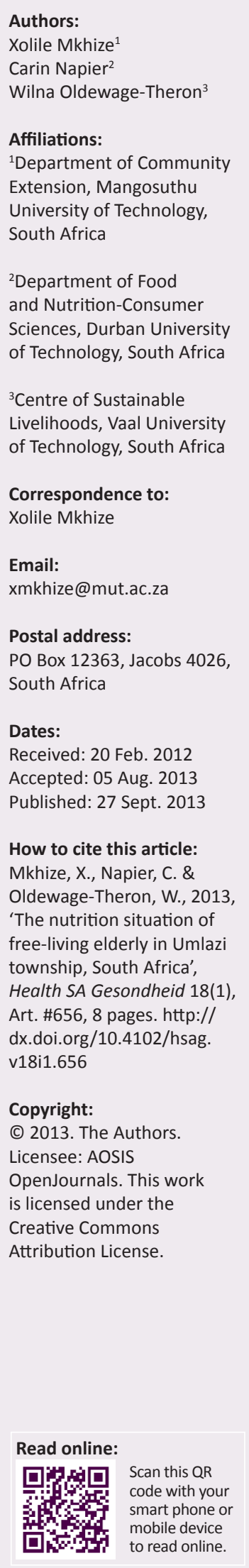

The risk for non-communicable diseases such as hypertension, diabetes, stroke and ischaemic heart disease in the elderly continues to be on the increase. It is shaped and modified by factors such as economic status and experiences across the whole lifespan. Although malnutrition in this population could be due to poor dietary practices, the nutrition transition of communities in South Africa is partially responsible for nutritional problems. Because of the degree of dependency on others for help and care in communities, the elderly are at risk for malnutrition. The elderly of the Umlazi community are overburdened with the social responsibility of grandchildren and trying to bring stability by managing various households. This becomes a double burden and puts more strain on their quality of life, further impacting on their nutritional status.

Die risiko vir chroniese siektes soos hipertensie, diabetes, beroerte en hartkwaal is steeds baie hoog in die bejaardes in Suid Afrika. Dit word deur faktore soos ekonomiese status en ervarings oor die hele lewesiklus gevorm en verander. Voedings probleme wat geïndentifiseer is in die studie hou verband met dieettekorte, alhoewel probleme met oorvoeding verband kan hou met die voedings oorgang wat plaasvind in Suid Afrikaanse gemeenskappe. In verskeie gemeenskappe, as gevolg van die graad van afhanklikheid van ander vir hulp en sorg, is die bejaardes blootgestel aan die risiko van wanvoeding. Die bejaardes van die Umlazi gemeenskap is oorlaai met die sosiale verantwoordelikheid van kleinkinders en probeer om verskeie huishoudings te stabiliseer, wat 'n dubbele las op hulle plaas en dit kan hulle lewenskwaliteit affekteer wat dan hul voedingstatus verder kan vererger.

\section{Introduction}

\section{Problem statement}

South Africa has the fastest-growing elderly population in the southern African region (May 2003:25), but there is a paucity of literature regarding the nutritional status of the elderly in South Africa. In South Africa the elderly made up 8\% of the population in 2011 (Statistics South Africa 2011) and this figure is expected to reach $19 \%$ by the middle of the century (United Nations Population Division 2006). Elderly women constitute $61.7 \%$ of the population aged 60 years and over, a figure that rises to $68.1 \%$ in the population aged 80 years and over (Statistics South Africa 2005a, 2006b).

According to Aboderin (2007) and Peltzer, Schneider and Makiwane (2012), there has been limited research on the health and wellbeing of this population group and there are only poor interventional strategies to address their needs, particularly in African countries. Malnutrition continues to be a global problem affecting the elderly as it leads to increased hospital admissions, morbidity and higher rates of mortality (Charlton 2012).

In a study undertaken by Hickson in the United Kingdom, almost two-thirds of general- and acute hospital beds were used by people aged over 65. People over 75 years also stayed in hospital longer (Hickson 2006). The relationship between the underlying causes of malnutrition and food insecurity in South Africa needs urgent attention from researchers since limited empirical data is available for groups such as elderly women and men (Oldewage-Theron et al. 2005b).

Lack of physical activity, excessive weight gain and inadequate dietary intake increase the risk of developing non-communicable diseases during old age, especially in urban areas (Vorster 2002:243). According to Charlton, Ferreira and Du Plessis (2008), despite the pension income that the elderly receive, household food insecurity has been found to be the greatest in elderly-headed households in South Africa as a result of higher poverty risk and big household membership. Elderly people, especially women, who share pension income with other household members 
may also be at risk of inadequate dietary intake, as they often skip meals in favour of their grandchildren who can then benefit from the food that is available.

The exact prevalence of malnutrition amongst the elderly in South Africa is, however, not clearly defined, because no national surveillance programme exists at present. Little data are available because studies have been undertaken amongst isolated groups (Oldewage-Theron et al. 2008:4). Recently, the elderly have been identified as a group in which research is needed in order to determine food and dietary intake patterns in South Africa (Van Heerden \& Schonfeldt 2011).

The purpose of this study was, therefore, to conduct a nutrition situational analysis of elderly people on state pension living in Umlazi, KwaZulu-Natal, South Africa in order to determine if this community also suffered from similar problems to those reported in the literature. The researcher decided to investigate the sociodemographic- and health status as well as the food consumption patterns of this community. The study presents possible explanations for the nutrition situation amongst this elderly population group.

\section{Research objectives}

The objective of the study was to determine the nutritional situation in free-living elderly-headed households by assessing the socioeconomic status, health status, anthropometric measurements and dietary diversity of the sample.

\section{Contribution to the field}

South Africa has the fastest-growing elderly population in the southern African region, particularly in developing areas. This factor in the above literature highlighted the urgent need to study this group. The information obtained can be used to develop relevant nutrition-education programmes for the elderly.

\section{Research method and design}

The study was of a descriptive nature with a cross-sectional design. Descriptive nutrition studies describe the occurrence of disease and other health-related problems in communities and quantitative data that was well defined, organised and competently interpreted was gathered in order to identify variables affecting the outcome (Katzenellenbogen \& Joubert 2007). The quantitative data were collected using questionnaires during personal interviews.

\section{Population and sampling}

The sample was calculated using a power calculation (Cole 1997). The results of the power calculation indicated that a sample size of 263 respondents (from this population base of 17000 elderly people in Umlazi) was sufficient to generate statistically-significant representative data. The sample size was rounded off to 270 in order to account for possible dropouts. The sample size comprised 224 women and 46 men - systematically- and randomly-selected elderly people within the 12 wards of Umlazi. The inclusion criteria were for elderly persons aged 60 years and older who were permanent residents of Umlazi and registered pensioners with the South African Social Security Agency. People under the age of 60 , not resident in Umlazi and disabled persons were not included in the study. Each ward comprised 22 respondents who were interviewed, making a total of 270 respondents in the study. Using a loudhailer (to accommodate those with hearing problems) the researcher made an announcement in the Zulu language. This was done in each ward, in the community halls used as pension paypoints, a month before the study took place in order to orientate the elderly about the fieldwork which would taking place on their next pension date.

The announcement included information regarding the scope and purpose of the research and where it would take place. Consent forms were then signed during the interview process.

\section{Measuring instruments}

Fieldworkers trained through Durban University of Technology (DUT) departmental research workshops and qualified nurses completed the questionnaires and measurements in one-on-one interviews with the respondents. The fieldwork was conducted over a period of three months in the various Umlazi ward halls as indicated by the sampling strategy. The measurements and completion of questionnaires took about one hour per person to conduct and body assessments were completed in one session so that the elderly did not have to return for another session.

The food intake data, including dietary intake, were analysed using a standardised method on the FoodFinder software program version 3 developed by the Medical Research Council of South Africa. Food consumption data were analysed by a registered dietician.

\section{Sociodemographic questionnaire}

Sociodemographic variables are often used as a poverty indicator, seeing as poverty is a contributing factor to malnutrition, therefore this measuring instrument was an important inclusion for this nutrition study (Alkire \& Santos 2010). A pretested and validated sociodemographic questionnaire (Napier 2006) was used for assessment of socioeconomic status and included questions on personal information, accommodation and family composition, work and economic status, income and money spent on food per month, education and language and household assets. Fieldworkers assisted the elderly by translating information where required in order to improve their understanding of the questionnaire.

\section{Medical and health survey}

The health questionnaire used was a validated Gauteng Provincial Administration questionnaire that had been tested in an elderly community in Sharpeville (Oldewage-Theron et al. 2005a). Questions included self-reported information on 
the nature and severity of any health conditions as well as the use of alcohol, traditional medicines and type of healthcare service used. The questionnaire also included the actual blood-pressure measurements of the respondents.

\section{Anthropometry}

Anthropometric measurements included height and weight in order to calculate the Body Mass Index (BMI). Waist circumference and height measurements were taken so as to calculate the waist-to-hip ratio (WTHR). These measurements were taken according to World Health Organization (WHO) standard procedures. BMI was calculated by dividing weight $(\mathrm{kg})$ by height squared $\left(\mathrm{m}^{2}\right)$. The following cut-off point ranges were used: normal weight (BMI 18.5-24.9), overweight (BMI 25-29.9), obese I (BMI > 30), obese II (BMI > 35) and obese III (BMI > 40) (WHO 2004). Waist circumference calculations were conducted according to standard guidelines (Centers for Disease Control 2002). The waist-to-height ratio was calculated in order to determine the risk of metabolic syndrome in women and men, with a ratio of $>0.5$ indicating people at risk (Gibson 2005; Lee \& Nieman 2003). Blood pressure measurements were collected from the respondents twice by a registered nurse and the average of the two was recorded according to WHO standard procedures.

\section{Dietary assessment}

A 24-hour recall questionnaire (Oldewage-Theron et al. 2005a) was used in an interview situation to determine the food consumption of the elderly over 24 hours on three separate days - one weekend day and two weekdays - and a pre-validated food frequency questionnaire (FFQ) was used to determine the variety of food eaten. This questionnaire is a good indicator of the dietary diversity of food consumed over a period of seven days and is used to validate 24-hour recalls (Oldewage-Theron \& Kruger 2008). The fieldworkers assisted the elderly in estimating portion sizes, using food models and eating utensils to explain food items in order to assist with the memory of food consumed over the three days.

\section{Data analysis}

The Sociodemographic and Health questionnaires as well as the FFQ were captured onto an Excel ${ }^{(R)}$ spreadsheet by the researcher. Descriptive statistics (frequencies, means, standard deviations and confidence intervals) were determined for these variables with the assistance of a biostatistician using the Statistical Package for Social Sciences (SPSS) for Windows version 17.0 software program. The 24-hour recall data were captured and analysed using the FoodFinder version 3.0 computer software program by a Food and Nutrition specialist and presented in the form of means and standard deviations. The dietary reference intakes (DRIs) were used to compare the results for nutrient adequacy for a 51-70-year old population and presented in tables and graphs (FoodFinder3 2002; Langenhoven et al. 1991). Correlations were drawn so as to determine the relationship between various variables by using analysis of variance (ANOVA) statistical tests.

\section{Results \\ Sociodemographic data}

Table 1 indicates that the majority of respondents lived in brick houses $(229 ; 84.8 \%)$ and their living space generally consisted of more than three rooms $(236 ; 87.4 \%)$. However, the majority of households $(182 ; 67.4 \%)$ consisted of between four and 10 members whilst only 88 (32.6\%) of the households consisted of less than four members. The mean household size was $5.1( \pm$ SD 2.9) people.

The majority of respondents $(114 ; 82.9 \%)$ had a total monthly income of R500 - R1500, followed by R1501 - R2500 (31; $14.1 \%)$ and only 8 (3\%) had more than R2500 total income. Food expenditure for most households $(216 ; 80 \%)$ was > R500 of the total income. Food shortages due to limited income were frequent in 146 (54\%) of the households, who experienced this problem regularly (Table 2).

TABLE 1: Housing situation and members per household. $\dagger$

\begin{tabular}{lll}
\hline Variables & Number $(\boldsymbol{n}=\mathbf{2 7 0})$ & Percentage (\%) \\
\hline Type of house & 229 & 84.8 \\
Brick & 13 & 4.8 \\
Clay & 1 & 0.4 \\
Grass & 11 & 4.1 \\
Wood & 16 & 5.9 \\
Shack & 270 & 100 \\
Total & & \\
Number of rooms per household & 34 & 12.6 \\
$\leq 2$ rooms & 98 & 36.3 \\
3-4 rooms & 138 & 51.1 \\
$\geq 4$ rooms & 270 & 100 \\
Total & & \\
Children per household & 183 & 68.0 \\
Children & 87 & 32.0 \\
No children & 44 & \\
Number of other people living with elderly per household & 1.5 \\
None & 4 & 31.1 \\
1-3 & 84 & 39.6 \\
$4-6$ & 107 & 16.7 \\
$7-9$ & 45 & 11.1 \\
$>10$ & 30 & $5.1( \pm 2.9)$.
\end{tabular}

$\dagger$, Mean and standard deviation (SD) of people living per household $=5.1( \pm 2.9)$.

TABLE 2: Household bugdet in relation to food purchases of the respondents.

\begin{tabular}{lll}
\hline Variables & Number $(\boldsymbol{n}=\mathbf{2 7 0})$ & Percentage (\%) \\
\hline Total income per household & & \\
R500-R1000 & 178 & 65.9 \\
R1001 - R1500 & 46 & 17.0 \\
R1501-R2000 & 31 & 11.5 \\
R2001-R2500 & 7 & 2.6 \\
> R2500 & 8 & 3.0 \\
Food-buying shortages & & \\
Always & 146 & 54.0 \\
Often & 41 & 15.2 \\
Sometimes & 70 & 26.0 \\
Seldom & 7 & 2.6 \\
Never & 6 & 2.2 \\
Food-expenditure budget per month & & \\
< R250 & 19 & 7.0 \\
< R250-R500 & 29 & 11.0 \\
> R500 & 216 & 80.0 \\
Don't know & 6 & 2.0 \\
\hline
\end{tabular}




\section{Dietary intake data}

The top three food items consumed included maize-meal porridge (227.33 g), tea (160.96 g) and chicken stew (126.62 g) (Table 3$)$. The frequency of vegetable and fruit intake was very low; the portion sizes were also small and did not meet the recommended daily intake of $>400 \mathrm{~g}$ per day (Nishida et al. 2004). The first vegetable reflected on the top 20 foods list is cabbage $(84.67 \mathrm{~g})$ at number 10 , followed by spinach (144.96 g) in 11th position, but these were consumed by only a small number of people. The main sources of protein were chicken (126.62 g) and milk (56.90 g) whilst other sources which were consumed by the minority were beef (139.99 g), beans $(125.64 \mathrm{~g})$ and pilchards (133.94 g). Milk, however, was consumed by a large number of respondents $(n=114)$, but in inadequate quantities.

Table 4 indicates that the energy contribution from carbohydrates was $65 \%$ of the total energy intake, which is considered to be on the high side (World Health Organisation (WHO) goals 55\%-75\%).

Protein intake was adequate, with a $15 \%$ contribution to energy from protein, with $42.73 \mathrm{~g}$ and $40.23 \mathrm{~g}$ consumed by the women and men respectively (WHO goal 10\% - 15\%); and fat consumption contributed $20 \%$ to the energy for both men and women, meeting the goal set by the WHO, namely, $15 \%$ - 30\% fat intake (Table 4) (WHO 2003).
Table 5 indicates the mean macronutrient intakes for both men and women. The energy contributions showed that 198 $(89.2 \%)$ of the women consumed a diet that supplied $<100 \%$ of the Estimated Energy Requirements (EERs) and all of the men consumed $<100 \%$ of the DRIs for energy. Sixty-three per cent (139) of the women and 91.1\% (41) of the men consumed $<100 \%$ of the Recommended Daily Allowance (RDA) for protein. The mean carbohydrate intake in the sample was significantly higher than the daily requirements but even so, $9(4.1 \%)$ of the women consumed $<100 \%$ of the Estimated Average Requirements (EARs) for carbohydrates and all men consumed $>100 \%$. Table 5 also shows that $86.5 \%$ (192) of the women and $33.3 \%$ (15) of the men consumed $<100 \%$ of fibre requirements.

Table 6 indicates low intakes for the majority of the vitamins for both genders except for vitamin B12 and B6 (in the case of men only). Although the mean vitamin B12 intake was sufficient according to the EARs, $115(51.8 \%)$ of the women and $32(70 \%)$ of the men consumed $<100 \%$ of the EARs. The same is true for vitamin B6, where $39(86 \%)$ of the men had insufficient intake, although mean intake for the women was sufficient.

Low intake of the majority of minerals is reflected in Table 7 (as was also seen in Table 6 for vitamins) except for iron (36.6\% for men; $<100 \%$ requirement) and potassium $(39.0 \%$ for men; $<100 \%$ requirement). These were both consumed

TABLE 3: The mean top-20 food items ranked by total consumption (portion size $\mathrm{x}$ number of respondents) as measured by three $24-$ hour recalls $(n=267)$.

\begin{tabular}{|c|c|c|c|c|}
\hline No & Food item & Total intake & Mean intake (g) & Number \\
\hline 1 & Maize meal, cooked crumbly porridge & 60698.33 & 227.33 & 267 \\
\hline 2 & Tea, brewed & 42976.67 & 160.96 & 267 \\
\hline 3 & Chicken stew (with skin) & 13422.66 & 126.62 & 106 \\
\hline 4 & Bread/rolls, white/brown & 12951.66 & 84.65 & 153 \\
\hline 5 & Rice, white, cooked & 12760.40 & 83.95 & 152 \\
\hline 6 & Stew, beef, with vegetables & 11028.33 & 139.99 & 79 \\
\hline 7 & Beans, sugar, dried, cooked & 6659.16 & 125.64 & 53 \\
\hline 8 & Fresh milk, full cream & 6487.50 & 56.90 & 114 \\
\hline 9 & Samp and beans, $1: 1$ & 5685.83 & 270.75 & 21 \\
\hline 10 & Cabbage, cooked with potato, onion and sunflower oil & 4403.33 & 84.67 & 52 \\
\hline 11 & Spinach (swiss chard), cooked with potato, onion, sunflower oil & 3769.16 & 144.96 & 26 \\
\hline 12 & Steamed bread & 32363,33 & 1348.47 & 24 \\
\hline 13 & Sugar, white, granulated & 3171.50 & 14.09 & 225 \\
\hline 14 & Fruit punch (alcohol-free) & 2916.66 & 265.18 & 11 \\
\hline 16 & Mahewu/mageu, liquid & 2483.33 & 496.66 & 5 \\
\hline 17 & Coffee, brewed/instant & 2400.00 & 184.61 & 13 \\
\hline 18 & Breakfast cereal & 2231.00 & 123.94 & 18 \\
\hline 19 & Pilchards in tomato sauce & 2143.16 & 133.94 & 16 \\
\hline 20 & Tomato and onion, stewed (no sugar) & 2084.16 & 184.61 & 13 \\
\hline
\end{tabular}

TABLE 4: Intakes of macronutrients of the elderly in Umlazi compared against the World Health Organization (2003) nutrient-intake goals.

\begin{tabular}{|c|c|c|c|}
\hline Nutrient & Goal & Women $n=222$ & Men $n=45$ \\
\hline Total fat $(\% \mathrm{E})$ & $15 \%-30 \%$ & $20 \%$ & $20 \%$ \\
\hline Total protein (\% E) & $10 \%-15 \%$ & $15 \%$ & $15 \%$ \\
\hline Total carbohydrates (\% E) & $55 \%-75 \%$ & $65 \%$ & $65 \%$ \\
\hline Mean sodium (mg/day) & $<2000$ & 549.72 & 518.51 \\
\hline Dietary fibre (g) & $>25$ & 14.0 & 14.4 \\
\hline
\end{tabular}

$\% \mathrm{E}$, percentage of estimated energy requirement. 
TABLE 5: Analysis of three 24-hour recalls: Mean macronutrient intakes ( $n=267)$.

\begin{tabular}{|c|c|c|c|c|c|c|}
\hline \multirow[t]{2}{*}{$\overline{\text { Nutrient }}$} & \multirow{2}{*}{$\begin{array}{c}\text { Women } \\
(\text { mean } \pm \text { SD) } n=222\end{array}$} & \multirow{2}{*}{$\begin{array}{c}\text { Women } \\
(\%)<100 \% \text { of EAR }\end{array}$} & \multirow{2}{*}{$\begin{array}{c}\text { Men } \\
\text { (mean } \pm \text { SD) } n=45\end{array}$} & \multirow{2}{*}{$\begin{array}{c}\text { Men } \\
(\%)<100 \text { of DRIs }\end{array}$} & \multicolumn{2}{|c|}{ DRIs } \\
\hline & & & & & Men & Women \\
\hline Energy (KJ) & $4745.33 \pm 1232.55$ & 89.2 & $4793.07 \pm 1092.10$ & 100 & $8185.8 \mathrm{~kJ}$ EER $\dagger$ & $6316.8 \mathrm{~kJ}$ EER $\dagger$ \\
\hline Total protein (g) & $42.73 \pm 14.37$ & 63.1 & $40.23 \pm 11.84$ & 91.1 & $56 \mathrm{~g} /$ day & $46 \mathrm{~g} /$ day \\
\hline Carbohydrates (g) & $168.31 \pm 43.7$ & 4.1 & $174.91 \pm 47.26$ & 0 & $100 \mathrm{~g} /$ day $\S$ & $100 \mathrm{~g} / \mathrm{day} \S$ \\
\hline Total dietary fibre (g) & $14.15 \pm 5.82$ & 86.5 & $15.41 \pm 5.12$ & 33.3 & $30 \mathrm{~g} /$ day 9 & 25 g/dayq \\
\hline
\end{tabular}

Source: Food and Nutrition Board of the Institute of Medicine 2002; NICUS 2003

EAR, Estimated Average Requirements; EER, Estimated Energy Requirements; DRI, Dietary Reference Intakes.

$\dagger$, EER low-activity individuals $51-70$ and $>70$ years old.

$\$$, Recommended Dietary Allowances (RDA).

$\$$, Estimated Average Requirements (EAR).

\%, Adequate Intake (Al).

TABLE 6: Analysis of three 24-hour recalls: Mean vitamin intake in the elderly respondents $(n=267)$ compared against daily required intakes.

\begin{tabular}{|c|c|c|c|c|c|c|}
\hline \multirow[t]{2}{*}{ Nutrient } & \multirow{2}{*}{$\begin{array}{c}\text { Women } \\
\text { (mean } \pm \text { SD) } n=222\end{array}$} & \multirow{2}{*}{$\begin{array}{c}\text { Women } \\
(\%)<100 \% \text { of EAR }\end{array}$} & \multirow{2}{*}{$\begin{array}{c}\text { Men } \\
\text { (mean } \pm \text { SD) } n=45\end{array}$} & \multirow{2}{*}{$\begin{array}{c}\text { Men } \\
(\%)<100 \text { of EAR }\end{array}$} & \multicolumn{2}{|c|}{ DRIs } \\
\hline & & & & & Men & Women \\
\hline Vitamin A & $359.20 \pm 640.41$ & 89.0 & $445.92 \pm 776.31$ & 100 & $625.00 \mu \mathrm{g} /$ day $\dagger$ & $500.00 \mu \mathrm{g} /$ day $\dagger$ \\
\hline Vitamin D & $2.37 \pm 2.63$ & 98.2 & $2.42 \pm 2.74$ & 91.00 & $10.00 \mathrm{mg} / \mathrm{day} \ddagger$ & $10.00 \mathrm{mg} / \mathrm{day}$ \\
\hline Vitamin E & $4.47 \pm 2.58$ & 98.6 & $5.04 \pm 3.16$ & 95.6 & $12.00 \mathrm{mg} /$ day $\dagger$ & $12.00 \mathrm{mg} /$ day $\dagger$ \\
\hline Vitamin K & $88.36 \pm 133.16$ & 76.6 & $112.08 \pm 145.71$ & 91 & $120.00 \mu \mathrm{g} /$ day $\dagger$ & $90.00 \mu \mathrm{g} /$ day \\
\hline Vitamin B12 & $3.45 \pm 7.25$ & 58.1 & $2.01 \pm 2.14$ & 70 & $2.00 \mu \mathrm{g} /$ day $\dagger$ & $2.00 \mu \mathrm{g} /$ day $\dagger$ \\
\hline Vitamin B6 & $0.70 \pm 0.33$ & 95.5 & $2.57 \pm 7.78$ & 86 & $1.40 \mathrm{mg} / \mathrm{day}^{\dagger}$ & $1.30 \mathrm{mg} /$ day $\dagger$ \\
\hline Vitamin C & $33.79 \pm 44.7$ & 86.5 & $32.67 \pm 31.32$ & 93 & $75.00 \mathrm{mg} /$ day $\dagger$ & $60.00 \mathrm{mg} /$ day $\dagger$ \\
\hline Thiamin & $0.7 \pm 0.26$ & 82.9 & $0.76 \pm 0.29$ & 73 & $1.00 \mathrm{mg} /$ day $\dagger$ & $0.90 \mathrm{mg} /$ day $\dagger$ \\
\hline Riboflavin & $0.61 \pm 0.48$ & 82.9 & $0.63 \pm 0.45$ & 89 & $1.10 \mathrm{mg} /$ day $\dagger$ & $0.90 \mathrm{mg} /$ day $\dagger$ \\
\hline Niacin & $9.47 \pm 4.66$ & 71.6 & $9.08 \pm 4.58$ & 61 & $12.00 \mathrm{mg} / \mathrm{day} \dagger$ & $11.00 \mathrm{mg} /$ day $\dagger$ \\
\hline Folate & $150 \pm 89.05$ & 96.8 & $165.21 \pm 83.90$ & 77 & $320.00 \mu \mathrm{g} /$ day $\dagger$ & $320.00 \mu \mathrm{g} /$ day $\dagger$ \\
\hline Panthothenate & $3.73 \pm 2.06$ & 85.6 & $4.04 \pm 2.45$ & 64 & $5.00 \mathrm{mg} /$ day $\dagger$ & $5.00 \mathrm{mg} /$ day $\dagger$ \\
\hline Biotin & $18.51 \pm 14.63$ & 93.7 & $18.38 \pm 13.73$ & 84 & $30.00 \mu \mathrm{g} /$ day $\ddagger$ & $30.00 \mu \mathrm{g} / \mathrm{day} \ddagger$ \\
\hline
\end{tabular}

Source: Food and Nutrition Board of the Institute of Medicine 2002; NICUS 2003

DRI, Dietary Reference Intakes.

$\dagger$, Estimated Average Requirements (EAR).

+ Adequate Intake (Al).

TABLE 7: Analysis of three 24-hour recalls: Mean micro-mineral intakes of a sample of elderly respondents $(n=266)$ compared against daily required intakes.

\begin{tabular}{|c|c|c|c|c|c|c|}
\hline \multirow[t]{2}{*}{ Nutrient } & \multirow{2}{*}{$\begin{array}{c}\text { Women } \\
(\text { mean } \pm \text { SD) } n=222\end{array}$} & \multirow{2}{*}{$\begin{array}{c}\text { Women } \\
(\%)<100 \% \text { of EAR }\end{array}$} & \multirow{2}{*}{$\begin{array}{c}\text { Men } \\
\text { (mean } \pm \text { SD) } n=45\end{array}$} & \multirow{2}{*}{$\begin{array}{c}\text { Men } \\
(\%)<100 \text { of EAR }\end{array}$} & \multicolumn{2}{|c|}{ DRIs } \\
\hline & & & & & Men & Women \\
\hline Calcium & $240.42 \pm 175.91$ & 99.5 & $253.16 \pm 165.24$ & 98.0 & $1200 \mathrm{mg} /$ day & 1200 mg/day \\
\hline Iron & $6.11 \pm 3.23$ & 47.0 & $6.68 \pm 3.83$ & 38.6 & $6.00 \mathrm{mg} /$ day $\dagger$ & $5.00 \mathrm{mg} / \mathrm{day} \dagger$ \\
\hline Magnesium & $641.21 \pm 300.96$ & 92.3 & $189.28 \pm 48.34$ & 89.0 & $350.00 \mathrm{mg} /$ day $\dagger$ & $265.00 \mathrm{mg} /$ day $\dagger$ \\
\hline Potassium & $641 \pm 212.18$ & 41.4 & $645.07 \pm 180.10$ & 39.0 & $580.00 \mathrm{mg} /$ day $\dagger$ & $580.00 \mathrm{mg} /$ day $\dagger$ \\
\hline Choline & $334 \pm 310.11$ & 83.3 & $384.76 \pm 338.75$ & 82 & $550.00 \mathrm{mg} /$ day & $425.00 \mathrm{mg} / \mathrm{day} \ddagger$ \\
\hline Zinc & $6.06 \pm 2.33$ & 67.6 & $5.61 \pm 2.12$ & 77 & $9.40 \mathrm{mg} /$ day $\dagger$ & $6.80 \mathrm{mg} /$ day $\dagger$ \\
\hline Chromium & $23.23 \pm 14.56$ & 45.0 & $21.53 \pm 14.07$ & 73 & $30.00 \mu \mathrm{g} / \mathrm{day} \ddagger$ & $20.00 \mu \mathrm{g} / \mathrm{day} \ddagger$ \\
\hline Selenium & $12.95 \pm 10.08$ & 98.6 & $13.05 \pm 8.59$ & 95 & $45.00 \mu \mathrm{g} /$ day $\dagger$ & $45.00 \mu \mathrm{g} / \mathrm{day} \dagger$ \\
\hline lodine & $13.57 \pm 8.98$ & 0 & $12.19 \pm 7.24$ & 0 & $95.00 \mu \mathrm{g} /$ day $) \dagger$ & $95.00(\mu \mathrm{g} /$ day $) \dagger$ \\
\hline
\end{tabular}

Source: Food and Nutrition Board of the Institute of Medicine 2002; NICUS 2003

DRI, Daily Reference Intakes.

†, EAR, Estimated Average Requirements.

$\ddagger$, Adequate Intake (AI)

more amongst men than women. Although the majority of respondents had sufficient intake according to the EARs, the mean intake values for iron and potassium were still insufficient.

\section{Health data}

The anthropometric indices indicated that the mean weight of the respondents was $76.5 \mathrm{~kg}( \pm$ SD 17.3). The BMI scores for the total group indicated that $143(53 \%)$ of the respondents fell into the obese category (BMI > 30) (WHO 2004) and only $51(19 \%)$ were of normal weight. Although more men (16; $34.2 \%$ ) were overweight compared with women $(49 ; 21.9 \%)$, more women $(135 ; 60.1 \%)$ were obese compared with men $(9$; $18.8 \%$ ), as can be seen in Table 8 .

The majority $(186 ; 83 \%)$ of the women were above the cut-off point for waist circumference ( $\geq 88 \mathrm{~cm}$ ), with $38(17 \%)$ falling within the normal range, whilst $34(74 \%)$ of the men were within recommended cut-off points $(\geq 102 \mathrm{~cm}$ ) and only 12 (26\%) exceeded the recommended scores, indicating central obesity (Gibson 2005; Lee \& Nieman 2003). The overall results indicate that $208(77 \%)$ of the respondents were at risk of developing metabolic syndrome as they had a $>0.5$ waist-to-height-ratio, although $62(23 \%)$ fell into a lower-risk category. Women showed a higher risk (87.4\%) and men only 
$47.9 \%$ for metabolic syndrome. These results correlate with a WHO-SAGE wave 1 national study by the Medical Research Council and the South African Department of Health which indicated trends of overweight, obesity and central obesity measurements in older women (Peltzer et al. 2012).

The blood-pressure data collected indicate that the majority of the elderly population were in various stages of hypertension. Sixteen $(6 \%)$ were in the pre-hypertension stage, $76(28 \%)$ and $167(62 \%)$ were characterised as being at stage 1 and stage 2 hypertension respectively, whilst only 11 (4\%) reflected normal blood pressure (Table 9).

\section{Ethical considerations}

Ethical approval for the study was obtained from the Faculty Research Committee at the Durban University of Technology. The protocol was submitted in accordance with the Medical Research Council guidelines for medical research. Permission was granted by the eThekwini municipality to conduct interviews in municipal halls which are used as pension sites. All voluntary respondents were requested to sign an informed consent form prior to the study being undertaken. Study numbers were allocated to each respondent in order to ensure confidentiality.

\section{Recruitment procedures}

The recruitment process was conducted at pension paypoints in Umlazi. Systematic sampling was conducted in this study: a random first number was selected and from then onwards every 10th person on the total list was chosen systematically for inclusion in the sample. This method is technically referred to as a systematic sample with a random start. All 12 wards have a pension day schedule for the month and samples were selected on pension day in each ward.

\section{Informed consent}

All the respondents were required to complete a consent form to participate in the study after listening to the researcher explaining the purpose of the study. All participation was on a voluntary basis and respondents understood that they could withdraw at any time.

\section{Data protection}

All respondents were allocated a number and no names were used during the study. The names and numbers of the respondents are kept under lock and key at the Durban University of Technology and no one has access to it except for the researchers. After five years the list of names and numbers will be destroyed.

\section{Validity and reliability}

Credibility was ensured in terms of the competence of both the supervisors who were trained professionally in the field of nutrition and nutritional assessment and registered
TABLE 8: Body Mass Index (BMI) classification table for men and women.

\begin{tabular}{lcc}
\hline BMI Classification & \% of Men $\boldsymbol{n}=\mathbf{4 6}$ & $\mathbf{\%}$ of Women $\boldsymbol{n}=\mathbf{2 2 4}$ \\
\hline Underweight & $4 \%$ & $4 \%$ \\
Normal Weight & $43 \%$ & $14 \%$ \\
Overweight & $34.2 \%$ & $21.9 \%$ \\
Obese I (30.00-34.99) & $18.8 \%$ & $60.1 \%$ \\
Obese II (35.00-39.99) & - & - \\
Obese III ( $\geq 40)$ & - & - \\
\hline Total & $\mathbf{1 0 0 \%}$ & $\mathbf{1 0 0 \%}$ \\
\hline
\end{tabular}

TABLE 9: Hypertension classification table for the Umlazi elderly population.

\begin{tabular}{lccc}
\hline Classification & \multicolumn{2}{c}{ Parameter } & $\begin{array}{c}\text { Population } \\
\text { (\%) }\end{array}$ \\
\cline { 2 - 3 } & $\begin{array}{c}\text { Systolic Pressure } \\
(\mathbf{m m ~ H g})\end{array}$ & $\begin{array}{c}\text { Diastolic Pressure } \\
(\mathbf{m m ~ H g})\end{array}$ & \\
\hline Normal & $<129$ & $<80$ & $4.0 \%$ \\
Prehypertension & $120-139$ & $80-89$ & $6.0 \%$ \\
Stage 1 & $140-149$ & $90-99$ & $28.0 \%$ \\
Stage 2 & $>160$ & $>100$ & $62.0 \%$ \\
\hline Total & - & - & $\mathbf{1 0 0 \%}$
\end{tabular}

with the Health Professions Council of South Africa. The questionnaires used in this study were validated in previous studies as reported in the section on measuring instruments, therefore making them valid and reliable measuring instruments. The weight was measured using a PPS Physician scale from Scales 2000 and the height was recorded using a stadiometer. Both measurements were taken twice to ensure accuracy (Lee \& Nieman 2010). The same scale and stadiometer were used for all the respondents in order to ensure the validity of the measuring instruments.

A qualified nurse was contracted to assist with bloodpressure- and waist-circumference measurements. The waist measurements were taken using a non-stretchable measuring tape $(\mathrm{cm})$.

\section{Discussion}

The results of this study indicate the prevalence of poverty and food insecurity, as well as poor nutritional status, which compromises the quality of life of the elderly living in this community. Socioeconomic status plays a vital role in quality of life, including the food choices that these elderly are able to make. There are high levels of extreme poverty due to pension being the dominant source of income and the elderly remain the breadwinners in the majority of households within this community (Charlton et al. 2008). Poverty, unemployment and the increasing social burden of children (who were mostly unemployed) and grandchildren, who form a major part of many households, are putting a great deal of strain on the limited financial resources of many pensioners. There is a correlation in this observation with a study that observed demographic changes of increasing numbers of people who have been seen playing a significant contribution to family welfare and income, according to the South African Department of Social Development (South African Department of Social Development 2001).

Trends of being overweight, obese and centrally obese were prevalent, particularly in women and the high prevalence 
of hypertension continues to be a risk for other lifestyle diseases. High blood pressure has been identified as a risk factor for chronic disease in older persons, amounting to 12 $19 \%$ of the total burden of disease particularly in developing countries (United Nations Population Fund [UNPF] and Help Age International [HAI] 2012). The results showed a statistically-significant correlation $(p=0.01)$ between BMI and reported blood pressure. Similar observations were made in a study that investigated the relationship between obesity and hypertension in South African Black women (Schutte et al. 2008). Degenerating health status is linked to disease progression. This is a public health concern, not only because it increases medical expenses but also because the increased intake of medication, in order to deal with this degenerating health status, affects the wellbeing of the elderly and can compromise their nutritional status (UNDP \& HAI 2012). In a similar study conducted in Sharpeville (Oldewage-Theron et al. 2008) similar food-consumption patterns were identified.

Low micronutrient intakes were observed amongst both male and female respondents. The results correlate with a study by Charlton, Kolbe-Alexander and Nel (2007) in Cape Town where the consumption of micronutrients in the elderly was also poor. Results confirmed by the nutrient intake data and top 20 list indicate that essential micronutrients such as potassium, magnesium and folate, which are essential in reducing risk for hypertension, were poorly consumed, which could have contributed to the higher prevalence of hypertension amongst this population group.

Lack of published data contributes to the limited reporting of possible explanations that could be relevant in further discussion within this population group.

\section{Limitations of the study}

Limitations included getting permission for conducting the research from the Ethekwini municipality, since the authorising members from the Mayor's office were not available. This delayed the implementation of the project. After permission had been obtained to conduct the fieldwork in the municipal halls, these venues became unsafe after the first session as they were also used for pension payouts, which presented security concerns. This made the elderly uncomfortable with regard to participating fully for long periods. The fieldwork was moved to outside the pension payout venues where a gazebo was erected and screens were put in place to ensure privacy. Because of time constraints and the elderly coming from various households to the research venue it was decided to capture all three of the 24-hour recall questionnaires on one day. This was done as close as possible to the previous weekend and the fieldworkers assisted the respondents by questioning in such a way that it would help the elderly to remember what they ate over the previous three days. Food models and household utensils such as plates, bowls, glasses and cups were used to assist with portion sizes estimation.

\section{Recommendations}

The elderly should be a priority in social development, health and nutrition programmes of countries in the Southern African Development Community (SADC) which currently target children, women (lactating and pregnant) and people living with HIV (Kimokoti \& Hamer 2008).

Effective nutrition intervention programmes need to consider economic, health, social and demographic factors and future research is needed to address the growing needs of this population group. More interventions are therefore needed: collaborative research between the Department of Social Welfare, Department of Health, Senior Citizens' Sector within municipalities and non-governmental organisations is essential for the success in rolling out any community programmes. Partnerships need to incorporate other organisations already involved in research and programme development.

Further research is required on the role of social grants with regard to the nutritional status of the elderly and the role of health services in South Africa in addressing malnutrition in the elderly.

\section{Conclusion}

Nutritional needs of the elderly in South Africa cannot be ignored as this problem continues to affect the elderly with compromised lifestyles due to physical-, psychological- and socioeconomic status. Risk factors are, however, multifaceted and numerous and can be instrumental in creating health concerns which interfere with nutritional status. Older adults, especially women (Puoane et al. 2002), are more vulnerable to malnutrition and to being overweight or obese, both of which contribute to a double burden of disease. More assistance programmes need to be implemented at both national- and community levels and should address all determinants of nutritional status in the elderly.

\section{Acknowledgements}

The research was funded by the Durban University of Technology.

\section{Competing interests}

The authors declare that they have no financial or personal relationships which may have inappropriately influenced them in writing this article.

\section{Author's contributions}

X.M. (Mangosuthu University of Technology) collected the data in the community, C.N. (Durban University of Technology) was the supervisor of the student and contributed to the writing of the manuscript and W.O-T. (Vaal University of Technology) was the external supervisor of the student and contributed to the writing of the manuscript. 


\section{References}

Aboderin, I., 2007, 'Understanding and responding to ageing, health poverty and social change in Sub-Saharan Africa: a strategic framework and plan for research' African Research on Ageing Network, viewed 23 November 2009, from http:// www.ageing.ox.ac.uk/files/afran_oxford_conf_research_ageing_africa_final report.pdf

Alkire, S. \& Santos, M.E., 2010, 'Acute multidimensional poverty: A new index for developing countries', OPHI Working Paper 38, University of Oxford.

Centers for Disease Control, 2002, 'Using the BMI-for age growth charts', viewed 25 February 2008, from http://www.cdc.gov/nccdphp/growthcharts/training/ modules/module1/text/module1print.pdf

Charlton, K.E., 2012, 'Keeping older adults on their feet: role of diet in the maintenance of independence', Proceedings from the 1st Africa Region Conference of Gerontology and Geriatrics - Africa Ageing beyond Madrid +10: 32 S7.1

Charlton, K.E., Ferreira, M. \& Du Plessis, L., 2008, 'The nutritional status and needs of older persons', in N.P. Steyn \& N. Temple (eds.), Community nutrition textbook for South Africa: A rights-based approach, pp. 555-590, South African Medical for South Africa: A rights-based approach, pp.
Research Council, Cape Town. PMid:18833749

Charlton, K.E., Kolbe-Alexander, T.L. \& Nel, J.H., 2007, 'The MNA, but not the DETERMINE, screening tool is a valid indicator of nutritional status in elderly Africans', Nutrition 23(7-8), 533-542. http://dx.doi.org/10.1016/j.nut.2007.04.015, PMid:17570641

Cole, T.J., 1997, 'Sampling, study size and power', in B.M. Margetts \& M Nelsons (eds.), Design concepts in nutritional epidemiology, pp. 64-86, Oxford University Press, New York. http://dx.doi.org/10.1093/acprof:oso/9780192627391.003.0003

Food and Nutrition Board of the Institute of Medicine, The National Academies, 2002 , 'Dietary reference intakes for energy, carbohydrates, fiber, fat, fatty acids, cholesterol, protein and amino acids', Journal of the American Dietary Association 102(11), 1621-1630. http://dx.doi.org/10.1016/S0002-8223(02)90346-9

Food Finder 3, 2002, Dietary analysis software program, version 1.0.7. South African Medical Research Council, Cape Town.

Gibson, R.S., 2005, Principles of nutritional assessment, 2nd edn., Oxford University Press, Oxford.

Hickson, M., 2006, 'Malnutrition and ageing', Postgraduate Medical Journal 82(963), 2-8. http://dx.doi.org/10.1136/pgmj.2005.037564, PMid:16397072, PMCid:PMC2563720

Katzenellenbogen, J. \& Joubert, G., 2007, 'Data collection and measurement', in G. Joubert \& R. Ehrlich (eds.), Epidemiology: A research manual for South Africa, 2nd edn., pp. 293-294, Oxford South Africa, Cape Town.

Kimokoti, R.W. \& Hamer, D.H., 2008, 'Nutrition, health and aging in sub-Saharan Africa', Nutrition Reviews 66(11), 611-623. http://dx.doi.org/10.1111/j.1753 4887.2008.00113.x, PMid:19019023

Langenhoven, M.L., Kruger, M., Gouws, E. \& Faber, M., 1991, MRC Food composition tables, 3rd edn., South African Medical Research Council, Parow, Cape Town.

Lee, R.D. \& Nieman, D.C., 2003, Nutritional assessment, 3rd edn., McGraw-Hill, New York.

Lee, R.D. \& Nieman, D.C., 2010, Nutritional assessment, 5th edn., McGraw-Hill, New York.

May, J., 2003, 'Chronic poverty and older people in South Africa', Chronic Poverty Research Centre Working Paper No. 25, viewed 14 August 2013, from http:// www.helpage.org/download/4c4a16227f1e4/

Napier, C.E., 2006, 'Evaluation of a feeding programme in addressing malnutrition in a primary school', D. Tech thesis, Food Service Management, Department of Hospitality and Tourism, Vaal University of Technology.

NICUS (Nutrition Information Centre University of Stellenbosch), 2003, 'Dietary reference intakes', viewed 20 October 2009, from http://www. sun.ac/nicus.pdf
Nishida, C., Uauy, R., Kumanyika, S. \& Shetty, P., 2004, 'The joint WHO/FAO expert consultation on diet, nutrition and the prevention of chronic diseases: process, product and policy implications', Public Health Nutrition 7(1A), 245-250. http:// product and policy implications', Public Health Nutrit
dx.doi.org/10.1079/PHN2003592, PMid:14972063

Oldewage-Theron, W.H., Dicks, E.G., Napier, C.E. \& Rutengwe, R., 2005a, 'Situation analysis of an informal settlement in the Vaal Triangle', Development Southern Africa 22(1), 13-26. http://dx.doi.org/10.1080/03768350500043794

Oldewage-Theron, W.H., Salami, L.I., Zotor, F.B., Matiwane, N. \& Venter, C.S., 2005b, 'The elderly and health: a case study from Sharpeville, South Africa', Proceedings of the Inaugural National Congress, Nairobi, Kenya, pp. 1-30.

Oldewage-Theron, W.H., Salami, L., Zotor, F.B. \& Venter, C., 2008, 'Health status of an elderly population in Sharpeville, South Africa', Health South Africa Gesondheid 13(3), 4-17.

Oldewage-Theron, W.H. \& Kruger, R., 2008, 'Food variety and dietary diversity as indicators of the dietary adequacy and health status of an elderly population in Sharpeville, South Africa', Journal of Nutrition for the Elderly 27(1/2), 101-133. http://dx.doi.org/10.1080/01639360802060140, PMid:18928193

Peltzer, K., Schneider, M., Makiwane, M., Zuma, K., Ramlagan, S., Tabane, C. et al., 2012, 'The health of older South Africans', Proceedings from the 1st Africa Region Conference of Gerontology and Geriatrics- Africa Ageing beyond Madrid +10: 26 S4.2.

Puoane, T., Steyn, K., Bradshaw, D., Laubscher, R., Fourie, J., Lambert, V. et al., 2002, 'Obesity in South Africa: the South African demographic and health survey', Obesity Research 10(10), 1038-1048. http://dx.doi.org/10.1038/oby.2002.141, PMid:12376585

Schutte, A.E., Huisman, H.W., Van Rooyen, J.M., Schutte, R., Malan, L., Reimann, M. et al., 2008, 'Should obesity be blamed for the high prevalence rates of hypertension in black South African women?' Journal of Human Hypertension 22(8), 528-536. http://dx.doi.org/10.1038/jhh.2008.35, PMid:18432254

South Africa Department of Social Development, 2001, 'Mothers and fathers of the nation: The forgotten people?', Vol. 1, Main report - Ministerial Committee on Abuse, Neglect, and III-treatment of Older Persons, viewed 25 March 2005, from http//www.welfare.gov.za/Documents/2001/March/elder.htm

South African Department of Health, 2007, 'Department of Health embarks on a national study on the health of older persons', viewed 15 March 2008, from http://www.hst.org.za/news/20041552

Statistics South Africa, 2006a, 'Mid-year population estimates, South Africa 2005 Statistical release P0302', viewed 26 February 2008, from www.statssa.gov.za/ publications/P0302/P03022005.pdf

Statistics South Africa, 2006b, 'Mortality and causes of death in South Africa, 2006: Findings from death notification', Statistical release P0309.3, viewed 16 January 2009, from www.statssa.gov.za/publications/ P03093/P030932006.pdf

Statistics South Africa, 2011, Population census for 2011, Stats SA Printer, Pretoria.

United Nations Population Division, 2006, Population ageing, Wallchart, New York.

United Nations Population Fund and Help Age International, 2012, Ageing in the twenty-first century: a celebration and a challenge, United Nations Population Fund, New York and Help Age, London.

Van Heerden, I.V. \& Schonfeldt, H.C., 2011, 'The lack of food intake data and consequences thereof', South African Journal of Clinical Nutrition 24(1), 10-18.

Vorster, H.H., 2002, 'The emergence of cardiovascular disease during urbanisation of Africans', Public Health Nutrition 5(1A), 239-243. http://dx.doi.org/10.1079/ PHN2001299, PMid:12027290

World Health Organization, 2003, Diet, nutrition and the prevention of chronic diseases, Report of a Joint WHO/FAO Expert consultation 2003, WHO Technical Report Series No. 916, WHO, Geneva.

World Health Organization, 2004, 'Global database on Body Mass Index', viewed 27 May 2008 from http://apps.who.int/bmi 